\title{
IZGRAĐENO OKRUŽENJE I REZILIJENTNOST GRADA
}

\author{
Aleksandra D. Krstić-Furundžić ${ }^{1}$ \\ UDK=711.426:504.61 \\ https://doi.org/10.18485/fb_ubur.2018.1.ch1 \\ ${ }^{1}$ Arhitektonski fakultet, Univerzitet u Beogradu, akrstic@arh.bg.ac.rs
}

\section{Sažetak}

Rast populacije, koji uzrokuje neizbežno širenje gradova, klimatske promene i rastuća oskudica konvencionalnih izvora energije, fosilnih goriva, rezultuju pojavom raznovrsnih problema i poremećaja, što predstavlja izazove za razvoj principa i strategija kako urbanog planiranja tako i projektovanja i gradnje zgrada koji će pomoći našim gradovima da se suoče sa uticajima tih stresova. Za povećanje rezilijentnosti grada kroz projektovanje zgrada važna su dva pitanja: smanjenje potrošnje energije proizvedene iz fosilnih goriva i smanjenje zagađenja životne sredine. Veći kapacitet rezilijentnosti grada u budućnosti uključuje i postizanje energetske i ekološke bezbednosti, što podrazumeva razvoj tehnologija za korišćenje obnovljivih izvora energije i u skladu sa tim strategija kako za projektovanje i gradnju novih zgrada, tako i za energetsku sanaciju postojećih zgrada. U tom smislu u radu se navode strateški principi za projektovanje i izgradnju zgrada.

Za ostvarenje energetski efikasnih zgrada omotač zgrade je najodgovorniji deo strukture zgrade. Osim zaštite od nepovoljnog vremena, osvetljenja i buke, komponente omotača zgrade dobijaju i ulogu proizvodnje energije. U radu se razmatraju inovativni koncepti i tehnologije materijalizacije omotača zgrada značajni za postizanje rezilijentnosti zgrada i time bezbednost životne sredine. Ukazuje se na projektantski koncept aktivnog odnosa zgrade i okruženja i u tom kontekstu razmatraju relevantne tehnologije i tehnička rešenja. Doprinos energetske sanacije zgrada rezilijentnosti grada pokazan je kroz diskusiju rezultata izvesnih prethodnih istraživanja. Pažnja je posvećena mogućnosti smanjenja potrošnje fosilnih goriva i zagađenja životne sredine, čime se doprinesi umanjenju klimatskih promena, što je jedan od aspekata postizanja urbane bezbednosti.

Ključne reči: rezilijentnost grada, energetska efikasnost zgrada, arhitektonske tehnologije, obnovljivi izvori energije, emisija $\mathrm{CO}_{2}$

\subsection{Uvod}

Gradovi su kompleksne i dinamične strukture koje postoje hiljadama godina, i pored mnogih različitih uticaja i procesa i rezultujućih problema i poremećaja, kao izazova kojima su gradovi stalno izloženi. Rapidan rast stanovništva izaziva dramatično širenje grada, kako u visinu tako i širinu, što izaziva bezbroj raznovrsnih problema sa kojima grad mora da se suoči i savlada ih. U tom smislu svaki grad 
ima specifičnosti, ali je u današnje vreme moguće izdvojiti nekoliko ključnih procesa koji generalno imaju kontinualno narastajući trend, a odnose se na:

- globalni porast broja stanovnika i migracije,

- intenzivnu potrošnju energije dobijene od konvencionalnih izvora energije, fosilnih goriva, i pored njihove sve manje raspoloživosti,

- zagađenje životne sredine $\mathrm{i}$

- klimatske promene.

Kao posledice navedenih procesa javljaju se negativni uticaju na životnu sredinu, a posebno se ukazuje na zagađenje vazduha, svetlosno zagađenje, buku i sindrom deficita prirodne sredine (Slika 1), koji se nepovoljno odražavaju na kvalitet života i zdravlje stanovnika u gradskim uslovima.

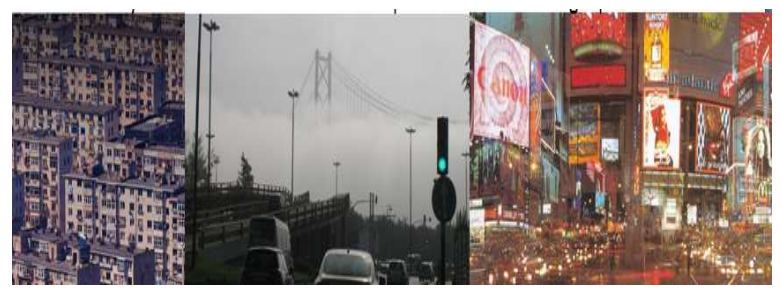

deficit prirodne sredine zagađenje vazduha, buka svetlosno zagađenje

Slika 1. Faktori negativnih uticaja na životnu sredinu u gradovima

Da bi se gradovi mogli u budućnosti odupreti negativnim uticajima pomenutih procesa, potrebno je stalno kreiranje i preispitivanje strategija za razvoj otpornosti gradova. Razvija se kompleksna ideja rezilijentnog grada.

Pod rezilijentnim gradom naučni i stručni krugovi podrazumevaju grad koji je razvio strategije i kapacitete koji mogu da pomognu apsorbovanje budućih poremećaja i stresova u njegovim socijalnim, ekonomskim i tehničkim sistemima i infrastrukturi, tako da bude u mogućnosti da održava neophodne postojeće funkcije, strukture, sisteme i identitet (ResilientCity.org, 2016). Pod pojmom rezilijentnost podrazumeva se sposobnost sistema, da apsorbuje poremećaje i da se reorganizuje dok prolazi kroz promene kako bi se održao identitet, odnosno zadržala osnovna struktura i način funkcionisanja, kao i sposobnost da se sagledaju povratne informacije i podaci o rezultatima (The Resilience Alliance; Walker et al., 2004).

Posebno je značajna sposobnost da se izvuku pouke iz procesa apsorbovanja nastalih poremećaja i na osnovu njih preispitaju i unaprede ili menjaju strategije za rezilijentnost grada, čime se nadgrađuje otpornost sistema i pomaže da se prevazilaze poremećaji.

Potrebno je da gradovi usvoje strategije urbanog planiranja i projektovanja i gradnje zgrada koje omogućavaju povećanje sposobnosti da se bolje odgovori i prilagodi ekonomskim, socijalnim i fizičkim poremećajima koji se javljaju (Slika 2), a uglavnom su povezani sa rastućom oskudicom konvencionalnih energenata, 
odnosno fosilnih goriva, klimatskim promenama i promenama stanovništva. Procene glase da će proizvodnja fosilnih goriva na globalnom nivou dostići maksimum u periodu između 2010. i 2020. godine, posle čega se očekuje pad proizvodnje i problem iscrpljenih izvora ovih goriva. Ovaj poremećaj se direktno odražava na rast cene ovih energenata, što dalje vodi u kompleksne probleme.

\section{Povećanje kapaciteta rezilijentnosti

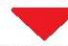 \\ GRADOVI TREBA DA USVOJE}

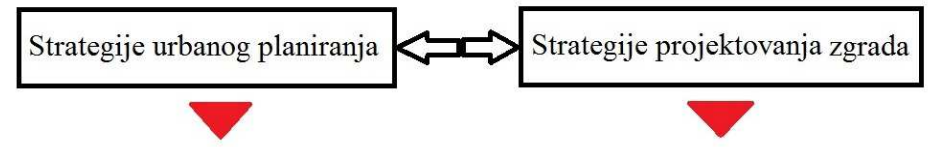

koje omogućavaju povećanje sposobnosti da bolje odgovore i prilagode se stresovima i poremećajima

\begin{tabular}{|l|l|l|}
\hline $\begin{array}{l}\text { promene i porst } \\
\text { broja stanovništva }\end{array}$ & $\begin{array}{l}\text { (ekonomskim, socijalnim i fizičkim) } \\
\text { sa kojima će se suočiti u budućnosti }\end{array}$ & $\begin{array}{l}\text { oskudica fosilnih } \\
\text { goriva; } \\
\text { klimatske promene }\end{array}$ \\
\cline { 2 - 2 } & \multicolumn{2}{c|}{ urbana bezbednost }
\end{tabular}

Slika 2. Način povećanja rezilijentnosti grada

Kada je reč o globalnom porastu broja populacije, predviđa se da će se rast populacije nastaviti najmanje do 2050. godine, sa dostizanjem broja od 9 milijardi žitelja u 2040. godini, dok je 11 milijardi prognoza za 2050. godinu (http://esa.un. org/unpp/wpp/). Prema Fondu Ujedinjenih nacija za stanovništvo, godina 2008. je označena kao ona kada je više od 50 procenata svih žitelja, 3,3 milijardi, živelo u gradskim područjima, a predviđanja glase da će ovaj broj narasti na 70 procenata do 2050 (UN, 2008). Isti izvor ukazuje da u Evropi 75 procenata populacije već živi u urbanim područjima, a predviđanja su da će ovaj broj dostići 80 procenata do 2020.

Ovakav porast broja stanovnika smatra se sa aspekta potencijala naše planete neodrživim. Rapidna migracija stanovništva u gradove dovodi do dramatičnog širenja gradova, prouzrokujući veliki broj raznovrsnih poremećaja i problema sa kojima se gradovi moraju suočiti, ne samo socijalnih već i onih koji se odražavaju na fizičku strukturu grada, zgrade i infrastrukturu, kao i identitet. Bez rezerve se može reći da gradovi imaju sa različitih stanovišta ogroman uticaj na životnu sredinu, ali najčešće u nepovoljnom smislu (Slika 1).

$\mathrm{S}$ obzirom na to da je u svetu prisutan građevinski fond sa velikim procentom zgrada koje su građene u periodima kada se nije vodilo računa o potrošnji energije potrebne za funkcionisanje zgrada, uočava se da on troši veliku količinu energije proizvedene od konvencionalnih energenata, fosilnih goriva. Taj problem se pojačava zbog intenzivne migracije stanovnika iz ruralnih i nerazvijenih manjih urbanih područja ka gradovima, kao i zbog snažnog industrijskog razvoja. Posmatrano u svetskim razmerama, gradovi troše između 60 i 80 procenata energije, i odgovorni su za veliku emisiju gasova staklene baste (UN, 2008), posebno ugljen-dioksida, što izaziva značajno zagađenje životne sredine i klimatske promene. U tome 
značajnu ulogu ima građevinski fond za koji se ocenjuje da je sa odgovarajućom infrastrukturom odgovoran za $50 \%$ emisije $\mathrm{CO}_{2}$, što narasta do $70 \%$ ako se priključi i emisija $\mathrm{CO}_{2}$ od transporta u gradovima (Jones et al., 2009).

$\mathrm{Na}$ globalnom nivou, ako se nastavi sa dosadašnjim trendom potrošnje fosilnih goriva, za nekoliko decenija emisija $\mathrm{CO}_{2}$ preći će nivo $450 \mathrm{ppm}$, koji se smatra granicom održavanja globalnog zagrevanja ispod $2^{\circ} \mathrm{C}$ (BBC, 2013; Jones, 2014). U svetlu prevencije od konflikata, zahteva se da politika prema klimi i energetska politika koncipiraju takvo snabdevanje energijom, koje će emisiju gasova sa efektom staklene bašte toliko prigušiti, da porast prosečne temperature na Zemlji do sredine 21. veka ne pređe $2^{\circ} \mathrm{C}$ (Lambić, 2009). U suprotnom će biti nesagledive posledice klimatskih promena za životnu sredinu, bezbednost biljnog i životinjskog sveta i izgrađenog okruženja.

S obzirom na procese u prirodi koji se sada dešavaju, upozorava se na moguće nestajanje koralnih grebena, menjanje uloge šuma u procesu apsorpcije ugljen-dioksida, posebno pretvaranjem 30-60\% tropskih kišnih šuma u suve savane, smanjivanje i potapanje ostrvâ usled porasta nivoa mora, sve češću pojavu uragana kategorije 5, povlačenje glečera usled toplih, suvih zima i sve toplijih leta, izazvanim globalnim otopljavanjem (EkoSpark.com). Isti izvor ukazuje da su najugroženija prostrana urbana područja koja bi mogla da u budućnosti budu pod vodom, što bi bila posledica promene nivoa mora uzrokovane globalnim zagrevanjem, tako da bi katastrofalne poplave u budućnosti uništile obalske gradove. Takođe, ovaj izvor iznosi da bi globalno zagrevanje moglo destabilizovati siromašne zemlje širom sveta, podstičući masovne migracije i stvarajući sve preduslove za širenje terorizma i da bi životni uslovi pogoršani efektima klimatskih promena mogli povećati masu potencijalnih regruta za terorističke organizacije.

Prethodno navedeni ključni procesi, koji imaju kontinualno narastajući trend, i za njih vezani poremećaji i problemi odražavaju se na urbanu bezbednost, doprinoseći kompleksnosti bezbednosnih pitanja. Sa različitih aspekata se može pristupiti razmatranju ovih pitanja i strategija za ostvarenje prilagodljivosti i otpornosti, odnosno rezilijentnosti gradova.

U ovom tekstu razmatranje je usmereno na izgrađenu sredinu, konkretno na zgrade čija uloga i značaj za postizanje urbane rezilijentnosti su diskutovani, odnosno njihov doprinos energetskoj i ekološkoj bezbednosti. U tom smislu, predmet razmatranja su strateška opredeljenja vezana za principe projektovanja i konstruisanja zgrada i primenu savremenih arhitektonskih tehnologija kako u slučajevima projektovanja novih tako i obnove postojećih arhitektonskih objekata. Metodološki pristup u radu obuhvata razmatranje odnosa rezilijentnosti zgrada i bezbednosti životne sredine, aktivnog odnosa zgrade i okruženja, u tom kontekstu strategija projektovanja zgrada i relevantnih tehnologija i tehničkih rešenja, i prikaz doprinosa obnove zgrada rezilijentnosti grada kroz diskusiju rezultata izvesnih prethodnih istraživanja. Pažnja je posvećena mogućnosti smanjenja potrošnje fosilnih goriva i zagađenja životne sredine, čime se doprinesi umanjenju klimatskih promena, što je jedan od aspekata za postizanje urbane bezbednosti. 


\subsection{Rezilijentnost zgrada i bezbednost životne sredine}

Kada je reč o povećanju rezilijentnosti grada kroz projektovanje zgrada, važna su sledeća dva pitanja:

- smanjenje potrošnje energije proizvedene od fosilnih goriva i

- smanjenje zagađenja životne sredine.

Rastući nedostatak energenata i klimatske promene prepoznati su kao ključni izazovi koji utiču na razvoj principâ i strategija urbanog planiranja i projektovanja zgrada koji će pomoći gradovima da savladaju ove nepovoljne uticaje. Strateške smernice za projektovanje zgrada su jedan od glavnih faktora za povećanje otpornosti grada. Važna je promena u sadašnjem shvatanju onoga što predstavlja dobar dizajn zgrade i odgovornu praksu izgradnje. U tom cilju moguće je ukazati na neophodnost prihvatanja sledećih strateških principa za projektovanje i izgradnju objekata:

- Korišćenje materijala, proizvoda i sistema za izgradnju zgrada koji imaju niski nivo ugrađene energije $\mathrm{i}$ emisije ugljen-dioksida u procesu njihove proizvodnje i ugradnje. U tom smislu daje se značaj primeni drveta kao građevinskog materijala i zidanih konstrukcija sa malom ugrađenom energijom. Takođe, primena niskoemisionih materijala i materijala koji se mogu reciklirati neosporni je prioritet. S obzirom da transport sa velikih rastojanja rezultuje potrošnjom goriva i emisijom $\mathrm{CO}_{2}$, poželjno je opredeljenje za lokalno proizvedene materijale i artikle. Zbog toga građevinski materijali, proizvodi i sistemi treba da budu dostupni kod lokalnih proizvođača i distributera, uz upotrebu lokalne radne snage. Izbor tehnologije gradnje treba da uzme u obzir uključivanje lokalne radne snage.

- Projektovanje i izgradnja zgrada kod kojih potrebna operativna energija sadrži niski procenat energuje od konvencionalnih izvore energije, fosilnih goriva. Zgrade moraju biti visoko energetski efikasne, dobro termički izolovane i sa komponentama zastakljenja sa visokim termičkim performansama, sa pasivnim solarnim sistemima za grejanje i termičkom masom za akumulaciju toplote. Za koncepte niskoenergetskih zgrada i zgrada nulte potrošnje potrebno je da omotač zgrade primi funkciju proizvodnje toplotne i električne energije. Takođe, neophodna je primena uređajâ za osvetljavanje, tehničke opreme i termotehničkih sistema sa niskom energetskom potrošnjom, takozvanih ,,̌tedljivih“ uređaja, u cilju smanjenja potrošnje električne energije i time manje emisije $\mathrm{CO}_{2}$, pošto je specifična emisija $\mathrm{CO}_{2}$ za električnu energiju po jedinici energije znatno viša u odnosu na druge vrste energenata.

- Projektovanje forme i strukture zgrade kojima se ostvaruje maksimalno prirodno osvetljenje i ventilacija unutrašnjeg prostora, pri čemu se efikasna rešenja vide u planiranju užih gabarita zgrada, sistema za usmeravanje dnevne svetlosti, unutrašnjih dvorišta i atrijuma.

- Potrebno je da projektantski koncept da omogući fleksibilnost zgrade tokom njenog životnog ciklusa kako bi se podržale adaptacija i obnova zgrade u cilju 
prilagođavanja budućim potrebama korisnika, promenama funkcije i unapređenjima tehničkih sistema, odnosno raznovrsnim budućim funkcijama.

- Postizanje trajnosti i robustnosti konstrukcije zgrada. S obzirom na klimatske promene koje izazivaju moguće incidentne situacije, klimatske (ekstremne temperature - toplotni i hladni talasi, suša, šumski i ostale vrste požara), hidrološke (poplava, bujica, olujni talas, priobalna poplava), i meteorološke (tropski cikloni i različite vrste oluja), materijali i konstrukcije moraju biti izdržljivi i trajni u tim uslovima. Robustnost konstrukcije je važna karakteristika zgrade sa aspekta bezbednosti, posebno značajna u okolnostima aktuelnog nastupanja terorističkih akcija. Čizmar i drugi (2011), razmatrajući probabilističke ocene robustnosti konstrukcija, ukazuju na sledeće definicije ovog pojma: sposobnost ispunjavanja određene funkcije pod različitim i promjenjivim uvjetima (Merriam-Webster Online, 2011); svojstvo sustava koje mu omogućava da preživi nepredvidive ili neobične događaje (Knoll and Vogel, 2009); prema evropskim normama robustna konstrukcija jeste konstrukcija kod koje su posljedice otkazivanja konstrukcije proporcionalne djelovanju koje je izazvalo otkazivanje (CEN, EN 1991, 2004; CEN, EN 1990, 2006). Takođe, održavanje strukture zgrade i sistema, kao i upravljanje zaštitom od požara i prevencija, sastavni su deo strategije rezilijentnosti zgrada.

- Potrošnja vode u zgradi i oko nje, prečišćavanje otpadnih voda i podela/klasifikovanje otpada u zgradama neophodne su stavke za projektovanje zgrada u kontekstu planiranja bezbednosti.

Ove principe uvažavaju različiti sistemi sertifikacije energetske efikasnosti i ekoloških karakteristika zgrada u svetu, što potvrđuje njihov značaj.

Rešenja se traže u novim tehnologijama koje koriste obnovljive izvore energije i u strategijama kontrolisane/racionalne potrošnje energije kako bi se smanjila potrošnja energije proizvedene od fosilnih goriva i time zagađenje životne sredine, što doprinosi otpornosti i bezbednosti gradova.

Globalno, važno je prihvatiti činjenicu što za postizanje otpornosti treba biti svestan da je promenjivost stalna i da su predviđanja teška u svetu koji je složen i dinamičan (Ward, 2007).

Energetska performansa gradske infrastrukture i tehnika i materijali za gradnju kuća odlučujući su faktori za kapacitet rezilijentnosti grada (Applegath, 2012). Applegath smatra da je smanjenje potrošnje energije po stanovniku u gradovima krucijalno za smanjenje negativnih uticaja i stresova povezanih sa cenom energenata u budućnosti. On ističe da u slučaju novih zgrada, tehnologije za smanjenje potrošnje i proizvodnju energije moraju biti uključene u projektovanje omotača od samog početka, dok je za zatečene zgrade potrebno da se dobro termički izoluju kako bi bila prihvatljiva ugradnja infrastrukture za korišćenje obnovljivih izvora energije, kao što su solarni kolektori za zagrevanje sanitarne vode i proizvodnju električne energije. Na ovaj način zgrade stiču potencijal za dostizanje kategorije zgrada nulte energetske potrošnje.

Zgrade treba da budu tako projektovane da se umesto sadašnjih urbanih struktura, okarakterisanih velikom energetskom potrošnjom, razvijaju nove ili 
transformišu postojeće tako da ih odlikuje manje intenzivna energetska potrošnja i emisija ugljen-dioksida. U tom smislu je ključno da zgrade budu energetski nezavisne, odnosno proizvode energiju dovoljnu za svoje potrebe ili da proizvode veću količinu energije koja se može preusmeriti za druge potrebe zajednice. Urbanističkim rešenjem potrebno je da se omogući prijem Sunčeve energije preko fasadnih i krovnih ravni, te savremena rešenja urbanih struktura rezultuju iz simulacija osunčanosti i zasenčenja zgrada kako bi se odlikovale manjom energetskom potrošnjom i emisijom $\mathrm{CO}_{2}$ (Slika 3).

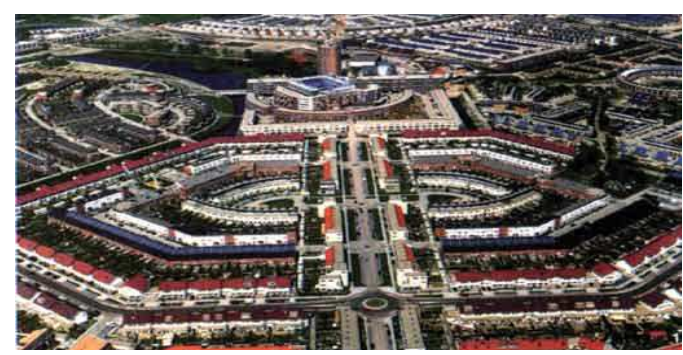

Slika 3. Avionski snimak nove varoši Nieuwland, pored Amersfoort-a, Holandija (Steemers, 2001)

Projektantski pristupi moraju uzeti u obzir aktivan odnos zgrade i njenog okruženja i moraju biti povezani sa specifičnostima geografskog položaja lokacije, običajima i nacionalnom istorijom, religijom i društvenim verovanjima kako bi ih prihvatilo stanovništvo.

\subsection{Aktivan odnos zgrade i okruženja - faktor rezilijentnosti zgrada}

Arhitektonski koncepti koji inkorporiraju aktivan odnos između zgrade i njenog okruženja proizlaze iz svesnosti o kompleksnosti, dinamičnosti i promenljivosti našeg okruženja.

Uspostavljanje aktivnog odnosa zgrade i njenog okruženja podrazumeva prilagođavanje: prirodnom i stvorenom okruženju, lokaciji, klimi, godišnjim i dnevnim ciklusima (promenama), kao i raznovrsnim potrebama korisnika. Ciljevi uspostavljanja aktivnog odnosa zgrade sa okruženjem jesu: ostvarenje optimalnog komfora boravka, maksimalne energetske uštede, odnosno smanjenje potrošnje fosilnih goriva i time zagađenja životne sredine. Rezultat uspostavljanja aktivnog odnosa zgrade sa okruženjem predstavljaju energetski efikasne strukture, a njihovo projektovanje se zasniva na postizanju odgovarajućih energetskih performansi.

U tom smislu, neophodno je da se uspostavi veza između zgrade i okruženja kreiranjem i implementacijom tehnologija grejanja, hlađenja, ventilacije i prirodnog osvetljavanja koje se baziraju na korišćenju prirodnih potencijala (razlike pritiska, temperature i vlažnosti) i obnovljivih izvora energije. To će omogućiti smanjenje potrošnje fosilnih goriva i zagađenja životne sredine, čime se doprinosi ublažavanju klimatskih promena. Ipak, treba imati u vidu da nove tehnologije i 
dizajn ponekad mogu biti generatori stresa (Furundžić et al., 2015), te je potrebno to uzeti u obzir pri njihovom odabiranju za konkterne uslove.

Razvoj tehnologija koje koriste obnovljive izvore energije i koje se mogu inkorporirati u strukturu zgrade, kao i arhitektonski koncepti i tehnologije zgrada nulte energetske potrošnje, presudni su za povećanje kapaciteta za rezilijentnost gradova i zgrada u budućnosti. Već godinama prisutno opredeljenje, a u mnogim zemljama regulativa, da se $25 \%$ i više energije potrebne za funkcionisanje zgrade proizvede od obnovljivih izvora energije, a sada u tehnološki razvijenim zemljama i opredeljenje da nove zgrade imaju skoro nultu potrošnju energije prozvedene od konvencionalnih energenata, kao i da tehničkim sistemima ugrađenim u svoju strukturu prozvode višak toplotne ili električne energije, učinili su da pasivni i aktivni solarni sistemi postaju nezaobilazan element u materijalizaciji omotača zgrada, dajući oblikovnu i vizuelnu prepoznatljivost zgradi i naselju.

Zbog funkcionalne kompleksnosti, omotači zgrada sa integrisanim toplotnim prijemnicima Sunčeve energije (STC) i fotonaponskim modulima (PV) mogu se smatrati multifunkcionalnim strukturama (Krstic-Furundzic et al., 2017). Integrisanje PV modula i STC u omotač zgrade zamenjuje konvencionalne materijale i rad, smanjujući cenu instalacije ovih sistema. Povećana upotreba obnovljivih izvora energije znači da integrisani sistemi toplotnih prijemnika (STSs) i fotonaponski moduli (PVs) imaju ključnu ulogu za snabdevanje strujom, toplom vodom i grejanje i hlađenje zgrada (Kalogirou, 2013).

Grejanje, hlađenje i osvetljenje su procesi koji su najveći potrošači energije u zgradama. Arhitektonski koncepti koji uključuju korišćenje solarne energije i prirodnih potencijala/sila rezultovali su pojavom novih arhitektonskih tehnologija koje sadrže nove sisteme, strukture i komponente materijalizacije zgrada. Interesantno je napomenuti da inspiracije za mnoga funkcionalna i tehnička rešenja poti$\breve{c u}$ iz tradicionalne arhitekture. Njihove forme često jasno ukazuju na ekološko opredeljenje.

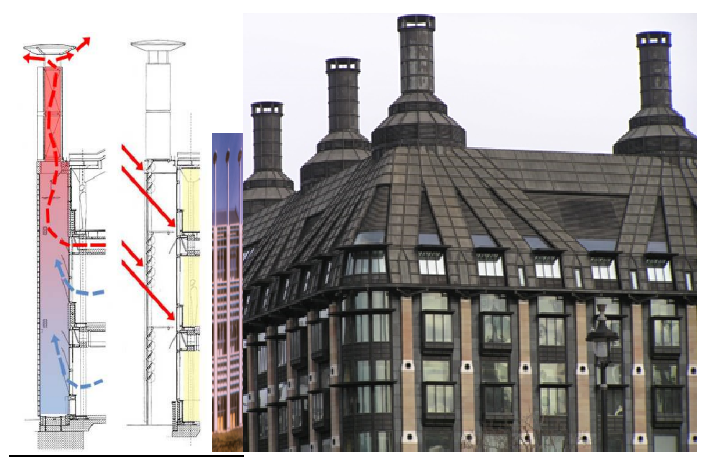

Slika 4. Komponente za ventilaciju pokrenutu prirodnim silama, $B R E$ Environmental office, Watford, UK (White, 2000), Portcullis House (PCH), London. Izvor: Autor 
Prirodna ventilacija obuhvata uvođenje tehničkih rešenja podsticanja prirodne cirkulacije vazduha u objektu kako bi se obezbedio vazdušni komfor bez velike potrošnje energije. U strukturu zgrade se uvode elementi za dopremanje svežeg vazduha iz okruženja i odstranjivanje zagađenog (,hvatači vetra“ i ventilacione vertikale) i predstavljaju vizuelno dominantne vertikale $\mathrm{u}$ formi zgrade, posebno krova (Slika 4). Takođe, u letnjem periodu omogućavaju noćno hlađenje konstrukcije zgrade, što je neophodno za sprečavanje pregrevanja i manju potrošnju energije za klimatizaciju objekta.

Strukture i komponente kojima se uvodi dnevna svetlost u prostore udaljene od fasadnih ravni omogućavaju smanjenje potrošnje električne energije, jer umanjuju potrebu za korišćenje veštačkog osvetljenja. Protežući se iz spoljašnjeg prostora duboko u središte zgrade uvode dnevnu svetlost putem različitih tehnika refleksije i usmeravanja dnevne svetlosti (Slika 5).

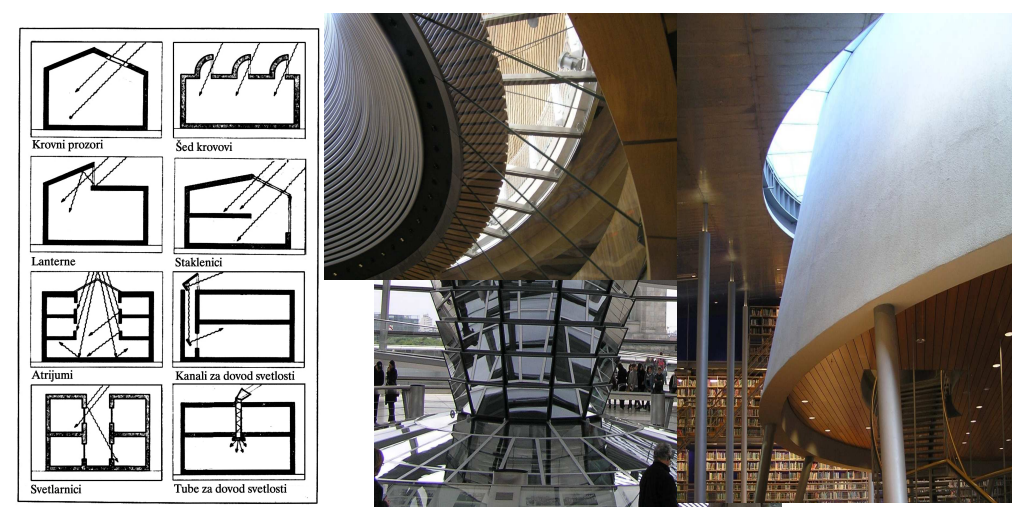

Slika 5. Tipovi (levo, Krstić-Furundžić, 2006) i primeri (desno) struktura za uvođenje dnevne svetlosti u zone zgrade udaljene od fasada. Primeri: The Senedd, Cardiff, gore; TU Delft biblioteka, sredina; Reichstag, Berlin, dole. Izvor: Autor

Primeri pokazuju da ove strukture postaju ključni element u kreiranju forme zgrade i njenog enterijera. Često su kombinovani sa sistemima za prirodnu ventilaciju zgrade.

Multifunkcionalni omotač zgrade mogu karakterisati sledeće funkcije:

- proizvodnja toplotne i električne energije,

- $\quad$ potencijal za grejanje, hlađenje i ventilaciju, i

- potencijal zaštite od Sunčevog zračenja uz propustljivost svetlosti i proizvodnju toplotne i električne energije.

Koncepti multifunkcionalnih i energetski efikasnih zgrada doprinose razvijanju novih struktura i komponenti omotača zgrada kao i tehnologija konstruisanja i gradnje. Mnogostruka funkcionalnost fasada može se ostvariti kombinovanjem već prisutnih tehničkih rešenja i sistema rezultujući u nove arhitektonske koncepte i izgled zgrada, kao i atraktivnost (Krstic-Furundzic, 2016a).

Sa aspekta ostvarivanja toplotnih dobitaka, uočavaju se dve osnovne funkcionalne grupe struktura i komponenti omotača zgrada: 
- komponente i strukture za direktne i indirektne solarne toplotne dobitke, i

- komponente i strukture za termičku kontrolu.

Shematski prikaz ovih komponenti dat je na Slici 6.
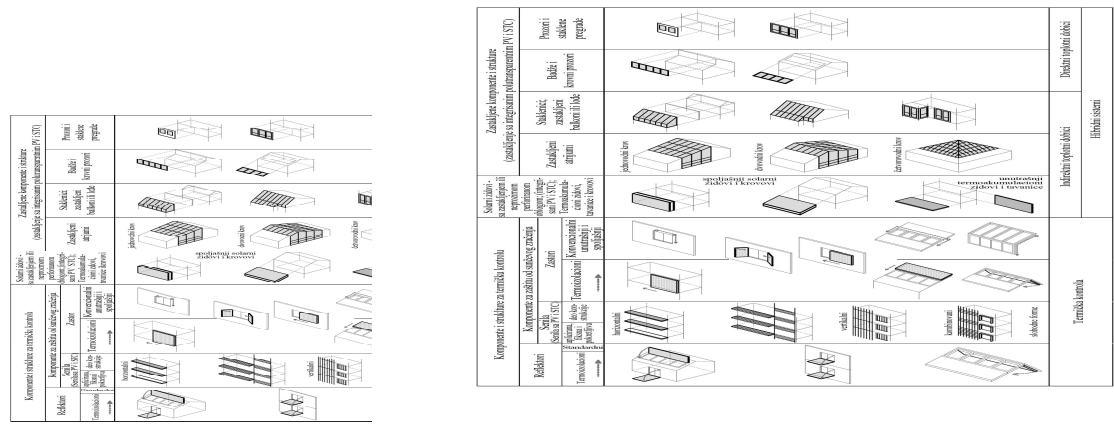

Slika 6. Komponente i strukture omotača zgrade za pasivno solarno grejanje i termičku kontrolu. Izvor: Autor

Komponente mogu biti različite geometrije, ravne ili zakrivljene, i organizovane u ortogonalne ili triangularne mreže, ili pak kreirati slobodne forme.

Staklo je uobičajeni materijal u sastavu konstrukcije komponenti i struktura za ostvarivanje toplotnih dobitaka od Sunčeve energije. U staklene površine tih komponenti i struktura mogu se integrisati neprozirni ili polutransparentni fotonaponski (PV) i toplotni (ST) kolektori, čime se omogućava efikasno snabdevanje strujom i toplom vodom i grejanje i hlađenje zgrade.

Pasivni solarni kolektori, kao Trombov zid i transparentne termoizolacije, koriste termičku masu zida kao termoakumulirajuću komponentu, čime su neki aspekti konstrukcije zgrade diktirani (Chan et al., 2010; Platzer, 2000). Konstruktivne karakteristike takvih kolektora, solarnih zidova, prikazane su na Slici 7. Većina raspoloživih sistema zid-zavesa može se primeniti za konstruisanje ovih zidova.
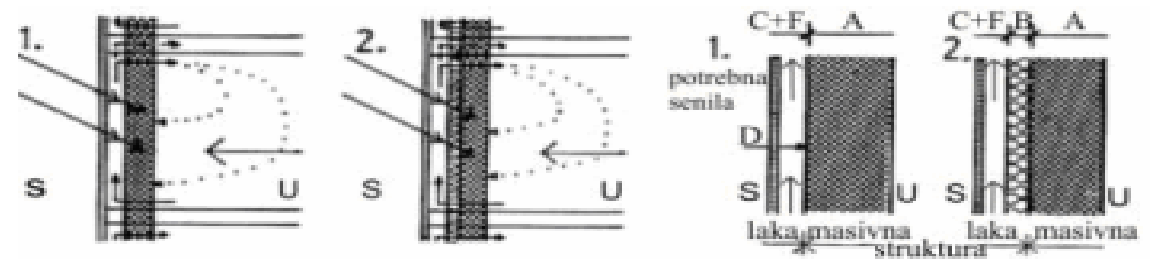

A - termoakumulaciona zona, B - termoizolaciona zona,

$\mathrm{C}$ - prostor zagrevanja vazduha, $\mathrm{F}$ - spoljašnja zaštitna zona,

D - tamno obojena površina; S - spolja, U - unutra

Slika 7. Konstruktivne karakteristike solarnih zidova -1 . Trombov zid i 2. Solarni zid sa transparentnom izolacijom (Krstic-Furundzic, 2000) 
Uspešan primer pasivnog solarnog kolektora - solarnog zida - jeste dupla fasada poslovne zgrade Solar Building XXI u Lisabonu, koja predstavlja hibridni sistem toplotnog prijemnika Sunčeve energije i PV modula (Slika 8). Južno orijentisana fasada sadrži vertikalne zone prozora i zone duple fasade sa PV modulima. Kroz prozore se ostvaruju direktni, a kroz duplu fasadu indirektni toplotni dobici.
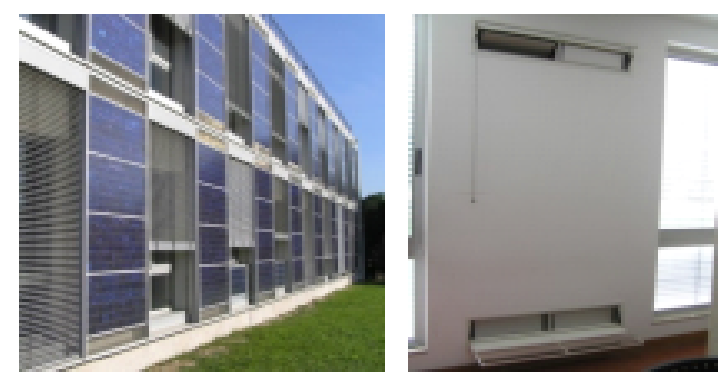

Slika 8. Poslovna zgrada Solar Building XXI, Lisabon. Dupla fasada sa PV modulima (levo) i pozicija otvora za cirkulaciju vazduha (desno). Izvor: Autor

Unutar duple fasade toplota rezultuje iz procesa konverzije Sunčeve energije u električnu u PV modulima. Delovi fasade tipa duple fasade imaju potencijal za grejanje i hlađenje zgrade i proizvodnju električne energije. Ventilacioni otvori kreirani u oba sloja duple fasade (Slika 8) omogućavaju prirodnu ventilaciju putem „efekta dimnjaka“, odnosno ventilaciju pokrenutu prirodnim silama. Kao što je prikazano na Slici 9, vazdušni prostor unutar duple fasade (iza PV modula) koristi se za zagrevanje svežeg vazduha u proleće (a) i vazduha ubačenog iz unutrašnjeg prostora zimi (b), ali i za sprečavanje pregrevanja zgrade u letnjim danima (c) i za hlađenje strukture zgrade tokom letnjih noći (d).

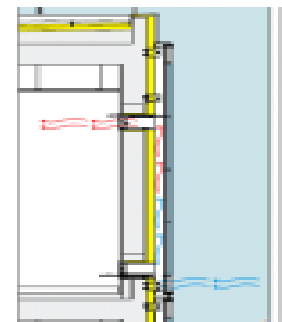

a)

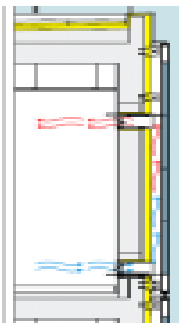

b)

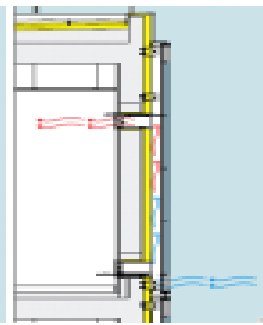

c)

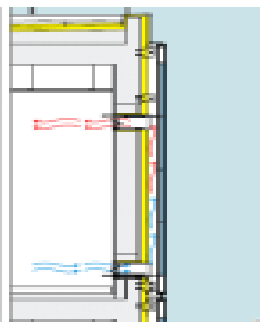

d)

Slika 9. Dupla fasada kao hibridni PV/T sistem, Solar Building XXI, Lisabon

(Gonçalves and Cabrita, 2010).

Oko $80 \%$ energije koja se troši u zgradi potiče iz obnovljivih izvora energije, te se zgrada Solar Building XXI uklapa u kontekst zgrada u budućnosti, a to su zgrade koje imaju nultu potrošnju enegije iz konvencionalnih izvora, "NZEB, Net Zero Energy Buildings" (Gonçalves and Cabrita, 2010). 
Sveobuhvatno razumevanje kombinacija različitih uticaja na omotač zgrade nameće da projektanti kreiraju fleksibilne i inteligentne strukture omotača, koje mogu reagovati na te uticaje u cilju obezbeđenja odgovarajućeg komfora boravka za korisnike, uz optimizaciju potrošnje energije u zgradi, a time i smanjenje emisije $\mathrm{CO}_{2}$. Senila su karakteristična vrsta takvih struktura i komponenti omotača kojima se jasno pokazuje aktivan odnos zgrade prema okruženju. Senilima se postiže pasivan način smanjenja prekomernih toplotnih dobitaka od Sunčevog zračenja, a dobre mogućnosti kombinovanja sistemskih modula u strukture senila na omotaču zgrade omogućavaju kako smanjenje potrošnje energije za hlađenje tako i korišćenje solarne energije, što je osetan doprinos uštedi energije (Roberts and Guariento, 2009).

Dinamički sistemi senila su trenutno izraziti faktor razvoja arhitektonskih tehnologija. Tehnike pokretanja senila klasifikuju se na sisteme sa manuelnim i automatizovanim nadzorom, i uključuju tehnologije čije projektovanje podrazumeva saradnju sa drugim disciplinama. Sistemi omotača sa senilima sa manuelnim nadzorom izrađeni su od elemenata koji se pomeraju, klize, rotiraju, obrću, direktno od strane korisnika u skladu sa njegovim potrebama. Automatizovani sistemi obuhvataju pametne materijale i različite inteligentne, dinamičke sisteme podržane sistemima centralizovanog nadzora (Building IT). Sistemi sa centralizovanim nadzorom često ne mogu odgovoriti na individualne potrebe, pa je izazov razvoj sistema koji će odgovoriti na pojedinačne potrebe korisnika, pamtiti vezu uslovi-zahtevi-reakcije. Ovo područje je u pogledu funkcionalnih, tipoloških i tehnoloških karakteristika vrlo kompleksno, a njegov razvoj vezan za ekonomski i tehnološki razvijena društva.

Realizacija novih arhitektonskih koncepata često je uslovljavala razvoj novih materijala i tehnika proizvodnje i gradnje, ali i razvoj novih materijala vodi u nove zamisli. Ako su dotaknute granice mogućeg, inspirisani smo da prevaziđemo granice sopstvenog materijalnog okruženja (Knaak et al., 2011). I tako, kao perpetuum mobile, odvija se kontinualni razvoj arhitektonskih tehnologija podstaknut razvojem različitih faktora i parametara koji posredno ili neposredno utiču na to (Krstić-Furundžić, 2016b).

\subsection{Energetska sanacija zgrada i rezilijentnost grada}

Doprinos energetske sanacije zgrada smanjenju zavisnosti kuća od fosilnih goriva i time smanjenju zagađenja životne sredine, biće diskutovan kroz rezultate izvesnih prethodnih istraživanja, odnosno nekoliko studija slučaja, od kojih je jedna realizovana, a dve su hipotetičke.

Prva studija slučaja je energetska sanacija omotača značajnog broja višeporodičnih stambenih zgrada u naselju Karaburma, Beograd, realizovana u periodu 2009-2012. Odnosi se na smanjenje potrošnje energije za grejanje za oko 43\% godišnje, ostvareno unapređenjem termičkih performansi omotača (Krstic-Furundzic and Djukic, 2014), postavljanjem termičke izolacije debljine $5 \mathrm{~cm}$ na fasadne zidove i $10 \mathrm{~cm}$ na krovnu ploču, prekidom termičkih mostova i zamenom prozora u 
svemu prema regulativi važećoj u to vreme. Proporcionalno smanjenje emisije $\mathrm{CO}_{2}$ nesumnjivo je ostvareno. Poštovanje značajno zahtevnije aktuelne regulative doprinelo bi mnogo većim uštedama, kao što se vidi u sledećem primeru.

Druga studija slučaja odnosi se na energetsku sanaciju omotača hipotetičkog modela lamele tipične višeporodične stambene zgrade u naselju Konjarnik, Beograd. Predložene mere energetske sanacije značajno su kompleksnije u odnosu na prethodni primer i obuhvataju ne samo uštedu energije za grejanje prostora unapređenjem termičkih performansi omotača, već i uštedu energije za grejanje sanitarne vode za domaćinstva kreiranjem nekoliko scenarija aplikacije toplotnih prijemnika Sunčeve energije (Krstić-Furundžić and Kosorić, 2009). Smanjenje godišnje potrošnje energije za grejanje prostora za oko $90 \%$ postignuto je sledećim merama: postavljanjem termičke izolacije debljine $15 \mathrm{~cm}$ na fasadne zidove i $22 \mathrm{~cm}$ na krovnu ploču, prekidom termičkih mostova, zamenom prozora savremenim tipovima i zastakljenjem lođa, a aplikacijom krovnih toplotnih prijemnika Sunčeve energije pod nagibom od $40^{\circ}$ omogućava se smanjenje godišnje potrošnje energije za grejanje vode za oko $50 \%$ dok kombinacija krovnih i fasadnih solarnih toplotnih kolektora različitih nagiba može rezultovati viškom toplotne energije (Krstić-Furundžić and Kosić, 2017). Isti autori konstatuju da kombinacija navedenih mera može rezultovati smanjenjem potrošnje energije od $88 \%$ do $96 \%$ te posledično smanjenjem emisije $\mathrm{CO}_{2}$.

$\mathrm{Na}$ osnovu navedenih rezultata u ovom radu se energetski i ekološki benefiti saglédaju na širem nivou. Ako bi mere za unapređenje energetskih performansi omotača bile primenjene na zgradama u celom naselju Konjarnik, moguće je aproksimativno proceniti da bi energetske uštede, zavisno od usvojenog scenarija mera uapređenja, iznosile od 63 do 69 miliona $\mathrm{kWh}$ godišnje, što bi uticalo na smanjenje emisije $\mathrm{CO}_{2}$ od oko $18.300 \mathrm{t}$ do $21.500 \mathrm{t}$ godišnje. Činjenica da je veliki broj stambenih naselja sa sličnim tipom stambenih zgrada zastupljen ne samo u Beogradu već i u drugim gradovima u Srbiji i Evropi - ukazuje na značajan potencijal za smanjenje potrošnje energije proizvedene od fosilnih goriva i time mogućnost zaštite životne sredine, što bi doprinelo povećanju rezilijentnosti gradova i bezbednosti života u njima.

Treća studija slučaja odnosi se na unapređenje energetskih performansi poslovne zgrade u Bloku 26, Novi Beograd, i uštedu energije postignutu integracijom fotonaponskih (PV) modula u omotač zgrade. U ovoj studiji slučaja urađeno je više hipotetičkih modela, varijanti integracije PV modula. Pokazano je da se varijantom integrisanja PV modula u fasadu objekta u parapetu (postavljeni vertikalno - ugao $90^{\circ}$ ) i dve linije senila iznad prozora pod uglom od $45^{\circ}$, respektabilna količina energetskih zahteva za osvetljenje može supstituisati (Krstić-Furundžić et al., 2017). Za slučaj ove varijante integracije, godišnja potrošnja primarne energije smanjena je za $102.000 \mathrm{kWh}$, a emisija $\mathrm{CO}_{2}$ za $54.000 \mathrm{~kg}$.

Električna energija proizvedena integrisanim PV modulima može zadovoljiti zahteve za 31,65\% godišnje potrošnje energije za osvetljenje. Smanjenje emisije $\mathrm{CO}_{2}$ procenjeno je da iznosi oko $32 \%$. To pokazuje da se smanjuje potrošnja energije proizvedene iz fosilnih goriva, što je posebno značajno u slučaju potrošnje 
električne energije, jer je faktor pretvaranja za proračunavanje godišnje primarne energije veoma visok, kao i specifična emisije $\mathrm{CO}_{2}$, što nedvosmisleno ukazuje na doprinos bezbednosti životne sredine.

S obzirom na to da u gradovima poslovne zgrade predstavljaju značajan deo građevinskog fonda, ovi rezultati pokazuju da integracija PV modula u omotač zgrade može doprineti otpornosti gradova. U poslovnim zgradama su značajni interni dobici, što prouzrokuje da je za hlađenje prisutna velika potrošnja električne energije. Važno je da se primenom PV modula što više supstituiše energija potrebna za hlađenje zgrade, ali to zahteva višestruko povećanje površine PV modula i uključivanje krovnih ravni kao površinâ za njihovu aplikaciju. Pošto dostupnost površina na omotaču zgrade pogodnih za primenu STC i PV modula direktno utiče na mogućnost supstitucije energije proizvedene iz fosilnih goriva, ključno je da se u procesima urbanog planiranja i projektovanja zgrada pozicioniranje ovakvih površina uzme u obzir od samog početka.

\subsection{Zaključak}

Gradovi su, kao kompleksne i dinamične strukture, izloženi mnogim različitim uticajima i procesima, i rezultujućim problemima i poremećajima. Moguće je izdvojiti nekoliko ključnih procesa koji generalno imaju kontinualno narastajući trend: globalni porast broja stanovnika i migracije, intenzivna potrošnja energije dobijene od konvencionalnih izvora energije, fosilnih goriva, i pored njihove sve manje raspoloživosti, zagađenje životne sredine i klimatske promene. S obzirom na negativne posledice navedenih procesa, razvija se kompleksna ideja rezilijentnog grada $u$ cilju apsorbovanja budućih poremećaja i stresova u njegovim socijalnim, ekonomskim i tehničkim sistemima i infrastrukturi.

Poremećaji i problemi, i za njih vezani stresovi, neminovno se odražavaju na urbanu bezbednost doprinoseći kompleksnosti bezbednosnih pitanja. Potrebno je da gradovi usvoje strategije kako urbanog planiranja tako i projektovanja i gradnje objekata koje doprinose povećanju energetske i ekološke bezbednosti, kao komponentama urbane bezbednosti.

Otpornost grada ključno je povezana sa dizajnom zgrada i tehnologijama koje podržavaju aktivnu vezu između zgrade i okruženja kroz implementaciju tehnologija grejanja, hlađenja, ventilacije i prirodnog osvetljavanja koje se baziraju na korišćenju prirodnih potencijala/sila i obnovljivih izvora energije. U radu su razmatrane takve tehnologije i strukture i komponente omotača zgrade koje iz njih rezultuju. Suština je da omotač može reagovati na kombinovane različite uticaje u cilju obezbeđenja odgovarajućeg komfora boravka za korisnike, uz optimizaciju potrošnje energije u zgradi, a time i smanjenje emisije $\mathrm{CO}_{2}$, čime se doprinesi umanjenju klimatskih promena, što je jedan od aspekata za postizanje urbane bezbednosti. 


\section{Literatura}

1. Applegath, C. (2012). Future proofing cities, Strategies to help cities develop capacities to absorb future shocks and stresses. http://www.resilientcity.org/site/ywd_craigapplegath/assets/pdf/future_proofing_cities_toolkit_by_craig_applegath_2012-0301sm.pdf (korišćeno 15. marta 2017).

2. BBC (2013). Web site http://www.bbc.co.uk/news/science-environment-22486153 (korišćeno 5. marta 2017.)

3. CEN, EN 1991. (2004). Eurocode 1 - Actions Of Structures - Part 1-7: General Actions: Accidental Actions, Brussels, European Committee for Standardization.

4. CEN, EN 1990. (2006). Eurocode - Bases of Structural Design, Brussels: European Committee for Standardization.

5. Chan, H. Y., S. B. Riffat and J. Zhu. (2010). Review of passive solar heating and cooling technologies. Renewable and Sustainable Energy Reviews, 14(2): 781-789. DOI: 10.1016/j.rser.2009.10.030.

6. EkoSpark.com, http://ekospark.com/info/01_eko_info/moguce_posledice_klimatskih_ promena/moguce_posledice_klimatskih_promena.html (korišćeno 25. februara 2017).

7. Gonçalves, H. and Cabrita, C. (2010). Solar XXI - Towards zero energy, LNEG Laboratório Nacional de Energia e Geologia, Lisbon, Portugal.

8. http://esa.un.org/unpp/wpp/ (korišćeno 25. februara 2017).

9. Jones, Phil, Jo Patterson and Chris Tweed (2009). Strategies for a Low carbon Urban Built Environment. European Carbon Atlas. The Welsh School of Architecture, Wales, UK, I-IX.

10. Jones, Phil (2014). Introduction. In: COST Action TU1104 - Smart Energy Regions. The Welsh School of Architecture, Cardiff University, UK, V-XII.

11. Kalogirou, S. A. (2013). Building integration of solar renewable energy systems towards zero or nearly zero energy buildings. International Journal of Low-Carbon Technologies, ctt071.

12. Knaak, U., T. Klein, M. Bilow and H. Techen (2011). Imagine 03 - performance driven envelopes. Delft University of Technology, Faculty of Architecture, 010 publishers, Rotterdam.

13. Knoll, F. and Vogel, T. (2009). Design for Robustness. Züurich: Iabse.

14. Krstic(-Furundzic), A. (2000). Measures and Techniques for Improvement of Thermal Performances of Inherited Buildings External Walls. Proceedings of the World Renewable Energy Congress - VI: Renewable Energy - Renewables: The Energy for 21th Century. Pergamon, UK, 356-361.

15. Krstić(-Furundžić), A. (2006). Multifunkcionalne krovne strukture energetski efikasnih zgrada. Arhitektura i urbanizam, 18/19: 34-47.

16. Krstic-Furundzic, A. (2016a). Architectural aspects of BISTS. Lecture at the Training school 3 of COST TU1205 Action, Warsaw. http://www.tu1205-bists.eu/2016/09/19/training-school-3/ http://www.tu1205-bists.eu/wp-content/uploads/sites/13/2016/09/2-2-Architecturalaspects-of-BISTS.pdf (korišćeno 30. oktobra 2016).

17. Krstić-Furundžić, A. (2016b). Faktori tehnološkog razvoja u savremenoj arhitekturi (Factors of technological development in modern architecture). Proceedings of International Scientific and Professional Conference on Contemporary Theory and Practice in Construction, Ed: Biljana Antunović, Univerzitet u Banjoj Luci, Banja Luka, 615-622. 
18. Krstic-Furundzic, A. and Djukic, A. (2014). Serbia. Smart Energy Regions, Eds: Phil Jones, Werner Lang, Jo Patterson, Philipp Geyer, The Welsh School of Architecture, Cardiff University, Wales, UK, 225-240.

19. Krstić-Furundžić, A. and Kosorić, V. (2009). 'Improvement of energy performances of existing buildings by application of solar thermal systems', Spatium International Review, 20: 19-22.

20. Krstić-Furundžić, A. and Kosić, T. (2017). Multicriterial optimization of the selection of the best measures for energy performances improvement of the multifamily housing in Belgrade. Proceedings of the 1st International Conference on Building integrated renewable energy systems - BIRES, Ed: S. A. Kolagirou, Dublin, Ireland, paper 13. http://www.tu1205-bists.eu/bires-conference/ (korišćeno 18. marta 2017).

21. Krstic-Furundzic, A., A. Savvides, G. Leindecker and C. Vassiliades (2017). Architectural planning/integration. COST Action1205 Building Integrated Solar Thermal Systems - Design and Applications Handbook, Ed: Soteris A. Kalogirou, COST Office, Brussels. Architectural planning/integration, 57-84.

22. Krstić-Furundžić, A., B. Sudimac and A. Dubljević (2017). Integration of PV modules into the building envelope in aim to achieve energy and environmental benefits. Proceedings of the 1st International Conference on Building integrated renewable energy systems - BIRES, Ed: S. A. Kolagirou, Dublin, Ireland, paper 14. http://www.tu1205-bists.eu/bires-conference/ (korišćeno 18. marta 2017).

23. Lambić, M. (2009). Energetske tehnologije - doprinos u smanjenju zagađenja životne sredine. Zbornik 1th International Conference Ecological Safety in Post-modern Environment, ICAMA, Banja Luka. http://apeironsrbija.edu.rs/icama2009/002-Miroslav\%20Lambic\%20-\%20Energetske\%20tehnologije.pdf (korišćeno 16. marta 2017).

24. Merriam-Webster Online (2011). Merriam-Webster Online rečnik.

25. Platzer, W. (2000). Transparent insulation materials and products: A review. In Y. Goswami (Ed.): Advances in Solar Energy, vol. 14: ASES, pp. 33-66.

26. ResilientCity.org (2016). Resilience. http://www.resilientcity.org/index.cfm?id=11449 (korišćeno 28. jula 2017).

27. Roberts, S. and Guariento, N. (2009). Building integrated photovoltaics: a handbook. Basel. Walter de Gruyter.

28. Steemers K. (2001). PV in the city, A design and implementation guide, Renewable Energy World, 4/6: 106-114.

29. The Resilience Alliance, http://www.resalliance.org/ (korišćeno 15. marta 2017).

30. UN (2008). World Urbanization Prospects: The 2007 Revision Population Database. New York: United Nations publication.

31. Furundzic, Z. N., P. D. Furundzic and A. Krstic-Furundzic (2015). Responsibility to the employees' health unavoidable in the creative and innovative design of office spaces. Proceedings of the 2nd International Academic Conference Places and Technologies - Keeping up with technologies to make healthy places. Eds: Fikfak, A. et al., University of Ljubljana, Faculty of Architecture, Slovenia, 610-616.

32. Čizmar, D., V. Rajčić, H. P. Kirkegaard and D. J. Sørensen (2011). Probabilistička ocjena robustnosti konstrukcija. Građevinar 63 (5): 431-439.

33. Walker, B., C.S. Holling, S.R. Carpenter and A. Kinzig (2004). Resilience, Adaptability and Transformability in Social-ecological Systems. Ecology and Society, 9(2): 5.

34. Ward, C. (2007). Diesel-driven bee slums and impotent turkeys: The case for resilience. http://www.tomsdispatch.com (korišćeno 15. januara 2017).

35. White, P. (2000). The Environmental Building, BRE Internet Services. 


\title{
BUILT ENVIRONMENT AND CITY RESILIENCE
}

\begin{abstract}
Summary
Cities are complex and dynamic structures that have existed for thousands of years despite many different influences and processes and resulting problems and disorders, which are the challenges that cities are continuously subjected to. In this sense, every city has its specific features, but nowadays, it is possible to distinguish several key processes with a continuously growing trend and related to: global population growth and migrations, intensive energy consumption in spite of decreasing availability of conventional energy sources, environmental pollution and climate change. For cities to be able to resist negative impacts of these processes in future, new and revised strategies for developing resilience of cities are needed.
\end{abstract}

Scientific and professional circles consider a resilient city to be a city that has developed strategies and capacities to help absorb future shocks and stresses to its social, economic, and technical systems and infrastructures so as to still be able to maintain essentially the same functions, structures, systems, and identity (ResilientCity.org, 2016). The term resilience means the capacity of a system to absorb disturbance and reorganize while undergoing change so as to still retain essentially the same function, structure, identity, and feedbacks (The Resilience Alliance; Walker et al., 2004).

Especially important is the ability to learn from the process of absorbing these disturbances - the ability to perceive the data and feedback on the results. This upgrades resilience of the system and helps to overcome disorders.

When it comes to global population growth, according to projections the world population will continue to grow until at least 2050, with the population reaching 9 billion in 2040, and some predictions putting the population in 2050 as high as 11 billion (http://esa.un.org/unpp/wpp/). According to the United Nations Population Fund, 2008 marked the year when more than 50 percent of all people, 3.3 billion, lived in urban areas, a figure expected to rise to 70 percent by 2050 (UN, 2008). The same source indicates that in Europe 75 percent of the population already lives in urban areas, and predictions are that this number will reach 80 percent by 2020. In terms of resources of our planet, this increase in the number of population is considered unsustainable. Rapid population migration to cities leads to a dramatic expansion of cities, causing a large number of various disorders and problems which cities have to face, not only social, but also those that reflect the physical structure of the city, buildings and infrastructure, as well as identity.

Given that the world's existing building stock includes a large percentage of buildings that were built during the periods when energy consumption for the building operation was not the subject of substantial consideration, it is observed that it consumes a large amount of energy produced by conventional energy sources, fossil fuels. This problem increases due to intensive migration of population from rural and underdeveloped smaller urban areas to the cities, and because of intensive industrial development. From a global standpoint, cities consume between 60 and 80 percent of electrical energy and are responsible for large emissions of greenhouse gases (UN, 2008), especially carbon dioxide, which causes consider- 
able environmental pollution, and climate change. Buildings and their supporting infrastructures are said to be responsible for emitting $50 \%$ of $\mathrm{CO}_{2}$ emissions, possibly rising to $70 \%$ if urban transportation is included (Jones et al., 2009). At a global level, if fossil fuels continue to be burnt at a 'business as usual' trajectory, in a matter of a couple of decades, we will cross the $450 \mathrm{ppm}$ level, taken as the limit for keeping global warming under $20^{\circ} \mathrm{C}$ (BBC, 2013; Jones, 2014). Assessments are that the production of fossil fuels globally will reach a maximum between 2010 and 2020, after which we are to face a decline in production and problems of exhausted sources of these fuels. This disorder has a direct impact on the growth of the price of these fuels, which can lead to complex problems.

The aforementioned processes and associated disorders and problems affect the urban safety contributing to the complexity of the security issues. These issues and strategies for the achievement of the flexibility and resilience of cities can be considered from different aspects. In this paper, consideration is focused on the built environment, respectively buildings whose role and importance for achieving urban resilience are discussed. In this sense, the subjects of discussion are strategic commitments related to the principles of design and construction of buildings and the use of modern architectural technology.

When it comes to increasing the resilience of the city through the design of buildings, the following two issues are important: reducing the consumption of energy produced from fossil fuels and environmental pollution. Increasing energy scarcity and climate change are recognized as key challenges affecting development of the principles and strategies of urban and building design which will help our cities to cope with the impacts of these stresses. The strategic guidelines for the design of buildings are one of the main factors to increase the resilience of the city. Solutions are expected with new technologies that use renewable energy sources and in strategies of controlled/rational consumption of energy. Overall, it is important to bear in mind that a resistant perspective acknowledges that change is constant and prediction difficult in a world that is complex and dynamic (Ward, 2007).

The energy performance of a city's infrastructure and building fabric is a key determinant of its capacity for resilience (Applegath, 2012). In the case of new buildings, technologies for conservation and energy production must be involved in their design from the very beginning, while the existing buildings need to be well thermally insulated in order to be suitable for the installation of infrastructure for the use of renewable energy sources such as solar collectors for water heating and photovoltaic modules. In this way, the buildings acquire the potential for reaching the category of zero energy buildings.

Buildings have to be designed in such a way to enable new or existing urban structures transform in less energy-intensive and less carbon-intensive ones, instead of the current urban structures characterized by high energy consumption. In this sense, it is essential that buildings are more energy independent, and can produce enough energy for their needs or produce a greater amount that can be directed to cover certain needs of the community. Design approaches should be connected to the uniqueness of the geographical origin of the community, their tradition and national history, religious and social beliefs, so that the population can accept them.

Architectural concepts that incorporate an active relationship between the building and its surroundings are resulting from the awareness of the complexity, dynamics and change- 
ability of our environment. An active relationship between the building and its surroundings involves the implementation of the technologies of heating, cooling, ventilation and natural lighting that are based on the use of natural forces (such as the pressure differences, differences in temperature and humidity), and the use of renewable energy sources. Development of renewable energy technologies that can be incorporated in buildings, as well as architectural concepts and technology of zero energy buildings are crucial to increase the resilience capacity of cities and buildings in the future.

In this paper, through a comparative analysis of case studies and the results of certain previous researches, relevant technologies and technical solutions are discussed and the importance of built environment, more exactly of buildings for achieving the resilience of the city is shown. Attention is paid to the possibilities of reducing fossil fuel consumption and pollution of the environment, thus contributing to reduction of climate change, which is one of the prerequisites if we want to achieve urban safety.

Keywords: city resilience, energy efficiency of buildings, architectural technologies, renewable energy sources, $\mathrm{CO}_{2}$ emissions 